\title{
EVALUASI MISFIT- SCORE STRATEGI PEMANUFAKTURAN DENGAN STRATEGI BISNIS SERTA DAMPAKNYA PADA KINERJA OPERASIONAL
}

\author{
Titik Kusmantini \\ Fakultas Ekonomi UPN "Veteran" Yogyakarta
}

\begin{abstract}
This research was established based on organizational kesesuaian hubungan theory, where in the formulation of strategic decision in manufacturing strategic must be alingment with business strategy. The higher congcruence can create higher performance. The hypothesis was tested with multiple regression models and the degree of fit (misfit-score) to computing with euclidean distance as regression coeficient.
\end{abstract}

Keyword: Manufacturing, Business, Performance, Misfit-Score.

\section{PENDAHULUAN}

Dalam konteks perekonomian Indonesia, seiring dengan munculnya krisis ekonomi yang berkepanjangan mengakibatkan perubahan besar dalam peta bisnis Indonesia. Banyak perusahaan besar yang pada awalnya diperkirakan akan mampu bertahan ternyata mengalami kebangkrutan. Sedangkan industri kecil dan menengah (IKM) yang mempunyai karakteristik "labor intensive" justru mampu bertahan. Dari sekitar 200.000 IKM di Indonesia saat ini ternyata 64\% kelompok ekonomi yang bergerak sebagai IKM tersebut mampu bertahan dari dampak krisis, bahkan 1\% di antaranya mempunyai pertumbuhan positif, 31\% mengurangi kegiatan bisnisnya serta $4 \%$ saja IKM yang terpaksa dihentikan usahanya (Sasono, 2002). Fenomena keberhasilan dan kegagalan perusahaan menimbulkan pertanyaan, mengapa ada perusahaan yang sukses dan ada yang tidak mampu bertahan hidup? Banyak faktor internal dan eksternal perusahaan yang mendorong perusahaan untuk mampu bertahan dari proses seleksi alam lingkungan bisnis.

Penelitian ini lebih menekankan pada aspek internal perusahaan, khususnya berkaitan dengan proses pengambilan keputusan strategi, baik strategi bisnis ataupun strategi pemanufakturan.Jadi penelitian ini bertitik tolak dari adanya perkembangan isu-isu penelitian yang menggunakan dasar implementasi strategi pada tingkat fungsional ataupun tingkat unit bisnis. Skinner (1978) menegaskan bahwa strategi pemanufakturan (manufacturing strategy) berbeda dengan strategi bisnis, karena strategi pemanufakturan hanya merupakan salah satu komponen fungsional, yang dalam implementasiannya perlu kesesuaian hubungan (fit) dengan strategi bisnis ataupun dengan strategi pemasaran. Oleh karena itu strategi pemanufakturan disebut sebagai a functional substrategy. 
Di era tahun 60-an kontribusi manufaktur terhadap kinerja perusahaan secara keseluruhan belum begitu signifikan (Skinner, 1969). Hal ini lebih banyak disebabkan karena top management sebagai pengambil keputusan tidak memahami adanya hubungan strategis antara bidang manufaktur dengan strategi bisnis. Sehingga sekumpulan (set) keputusan dan aktivitas yang ada di pabrik (bidang manufaktur) tidak dapat mendukung keputusan strategi bersaing ditingkat korporat. Mintzberg (1978) juga menegaskan pentingnya kesesuaian hubungan(alignment) antara strategi. bisnis dengan strategi pemanufakturan. Karena strategi bisnis merupakan suatu cara bagi perusahaan untuk menentukan posisi bersaing perusahaan, sementara strategi pemanufakturan merupakan satu cara untuk mencapai dan mempertahankan posisi bersaing yang diinginkan perusahaan tersebut. Untuk itu penting bagi setiap perusahaan untuk menentukan sumbersumber keunggulan bersaing dan menentukan keunggulan posisional (superior customer value atau lower relative cost) yang hendak dicapai perusahaan. Karena masing-masing keunggulan posisional membutuhkan kesesuaian strategi bisnis dengan sumber-sumber kompetensi fungsional organisasi (Day, GS dan Werssley, 1986), salah satunya adalah bidang produksi.

Berkaitan dengan keunggulan kompetensi di bidang pemanufakturan (produksi) Eisenhardt dan Marthin (2000) serta Anand dan Ward (2004) menekankan pentingnya pendekatan kontijensi, sebab proses pengembangan kapabilitas manufaktur sebagai basis kompetensi masing-masing perusahaan bersifat unik dan sepsifik yang sifatnya kontijen dengan sumber daya internal perusahaan ataupun keunggulan posisional yang ditargetkan dalam strategi bersaing. Perusahaan yang berorientasi sebagai pioneer pasar dengan perusahaan yang berorientasi sebagai imitator akan membutuhkan sumber daya dan kapabilitas di bidang manufaktur yang berbeda. Bahkan strategi bersaing perusahaan yang berorientasi sebagai marketer juga akan mempunyai pertimbangan kapabilitas manufaktur yang berbeda pula.

Konsep kesesuaian hubunganstrategi pemanufakturan dengan strategi bisnis juga dikemukakan oleh Skinner (1969) yang menandaskan bahwa kompetensi di bidang manufaktur memiliki potensi untuk memperkuat ataupun memperlemah kemampuan kompetitif perusahaan. Jika pilihan dan pengembangan kapabilitas manufaktur sesuai dengan pilihan strategi bersaing perusahaan maka akan menciptakan kinerja organisasi yang lebih tinggi. Konsep Skinner tersebut juga didukung oleh hasil penelitian Vickery, dkk (1993) yang juga menandaskan bahwa pilihan kompetensi bidang produksi yang kesesuaian hubungan dengan strategi bisnis akan membentuk sinergitas, sehingga interaksi kedua variabel tersebut akan menciptakan kinerja organisasi yang lebih tinggi dibandingkan pengaruh parsial.

Penelitian ini dibangun berdasarkan organizational fit theory yang dikemukakan oleh Galbraith dan Nathonson (1978), yang menyatakan bahwa strategi harus mempunyai kesesuaian hubungan dengan faktor-faktor internal perusahaan lainnya untuk dapat mencapai kinerja yang lebih baik. Konsep kesesuaian hubungan yang dimaksud di sini sesuai dengan definisi kesesuaian hubungan yang dikemuka- 
kan oleh Drazin dan Van de Ven (Riyanto, 1999), yaitu: "fit is the internal Consistency of multiple contigencies and multiple structural characteristic: it affects performance characteristics". Jadi kesesuaian hubungan adalah keterkaitan variabel-variabel internal organisasi yang akan berpengaruh pada kinerja, dan dalam penelitian ini secara khusus akan diuji derajat kesesuaian (degree of fit) hubungan strategi pemanufakturan dengan strategi bersaing. Dalam pengambilan keputusan dan pengimplementasian strategi pemanufakturan di tingkat fungsional perlu ada kesesuaian dengan pilihan strategi bersaing perusahaan yang secara eksplisit sebagai visi dan misi perusahaan dalam menentukan posisi bersaing perusahaan.

Secara rinci penelitian ini mempunyai tiga pertanyaan pokok. Pertama, apakah ada perbedaan pilihan kompetensi (manufacturing task) di bidang manufaktur pada perusahaan pengecoran dan rekayasa logam yang berada di Ceper (Kabupaten Klaten) dan di Tegal. Kedua, seberapa besar tingkat/derajat kesesuaian hubungan strategi pemanufakturan dengan strategi. Ketiga adalah untuk mengetahui besarnya pengaruh tingkat kesesuaian hubungan strategi pemanufakturan dengan strategi bisnis pada kinerja operasional pabrik.

\section{CONTIGENCY THEORY}

Teori kontijensi menyatakan bahwa dalam upaya pencapaian efektifitas, organisasi dituntut mempunyai keputusan dan kebijakan yang sesuai dengan struktur ataupun faktor-faktor internal organisasi lainnya. Begitupula kompleksitas praktikpraktik pemanufakturan suatu pabrik sifatnya kontijensi, sehingga pilihan kapabilitas manufaktur tertentu sebagai basis kompetensi lebih cocok untuk suatu perusahaan dan bisa saja kurang cocok untuk perusahaan lainnya. Jadi dalam teori kontijensi aspek kontekstual organisasi menjadi penting.

Tiga model pendekatan kontijensi menurut Drazin dan Van de Ven (Riyanto, 1999), pertama pendekatan seleksi (selection approach) yang menggunakan asumsi dasar kesesuaian sebagai kongkruensi antara faktor-faktor kontekstual organisasi menjadi hal mendasar tanpa harus menguji lebih lanjut kesesuaian hubungan tersebut berpengaruh pada kinerja atau tidak. Kedua adalah pendekatan interaksi (interaction approach) yang menggunakan asumsi dasar bahwa kesesuaian sebagai dampak interaksi antara strategi dengan variabel-variabel kontekstual organisasi, sehingga fokus penelitian pada penjelasan variasi kinerja sebagai akibat dari adanya interaksi variabel-variabel internal organisasi (sebagai variabel kontijensi) dengan strategi. Terakhir adalah pendekatan sistem (system approach) yang mendefinisikan kesesuaian hubungan sebagai konsistensi internal atas beberapa alternatif kategorikal kesesuaian dengan beberapa kategorikal struktur yang akan berpengaruh pada kinerja.

Dalam penelitian ini digunakan pendekatan sistem yang didasarkan pada beberapa hasil penelitian taksonomi strategi pemanufakturan. Kategorikal strategi pemanufakturan diadopsi dari hasil penelitian Sum, Kou dan Chen (2004) yang 
membedakan kelompok strategi operasi: Differentiators, all rounders dan efficientinnovators yang kesesuaian hubungan dengan kategorikal strategi bisnis Miles dan Snow (1978).

\section{MANUFACTURING STRATEGY}

Skinner (1969) mengartikan strategi pemanufakturan sebagai suatu proses pengambilan keputusan yang kompleks dan dinamis. Dikatakan komplek karena keputusan-keputusan penugasan dan aktivitas dalam area manufaktur harus kongkruen dan alignment dengan keputusan-keputusan korporat ataupun fungsi lain seperti keuangan ataupun pemasaran. Selain itu keputusan-keputusan dalam area manufaktur juga harus dinamis artinya mampu menyesuaikan dengan perubahanperubahan lingkungan yang terjadi.

Miller dan Roth (1994) menekankan dua elemen inti strategi pemanufakturan yang sebelumnya telah dikemukakan oleh Skinner (1969). Kedua elemen strategi pemanufakturan tersebut adalah manufacturing task dan pattern of manufacturing choice. Manufacturing task didefinisikan sebagai kapabilitas manufaktur yang dapat digunakan untuk mencapai dan mempertahankan posisional bersaing yang telah ditargetkan perusahaan. Skinner (1969); Hayes dan Wheelwright (1984); Ferdows dan De Meyer (1990); Roth dan Van De Velde (1991) serta Ward dan Duray (1998) menekankan ongkos produksi rendah, kualitas dan performansi produk, fleksibilitas, pengiriman produk dan tingkat inovasi sebagai lima kapabilitas kritis di bidang manufaktur.

Sementara pattern of manufacturing choice merupakan elemen kedua strategi pemanufakturan yang berkaitan dengan keputusan-keputusan struktural dan infrastruktural di pabrik guna mendukung pilihan kompetensi manufaktur. Keputusan struktural seperti fasilitas, teknologi, integrasi vertikal, kapasitas dan lokasi pabrik, sementara keputusan-keputusan infrastruktural berkaitan dengan struktur organisasi, manajemen kualitas, workforce policies, serta arsitektur sistem informasi. Namun demikian, dalam penelitian ini fokus penelitian hanya pada elemen manufacturing task yang disyaratkan harus kongkruen dan alignment dengan strategi bersaing perusahaan.

Beberapa penelitian sangat bervariasi dalam menggunakan ukuran variabel manufacturing task, misalnya Miller dan Roth (1994); Vickery, dkk (1993); Stoubough dan Telesio (1983) serta Avella, dkk (1998) menggunakan 11 dimensi, termasuk dimensi kompetensi di bidang pemasaran. Sementara Sum, Kou dan Chen (2004) menggunakan 8 dimensi manufacturing task yaitu ongkos produksi murah, fleksibilitas proses dan produk, kualitas dan reliabilitas produk, speed dan dependency delivery serta inovasi, sementara Vickery, dkk (1993) yang menggunakan sampel penelitian pada SME's menggunakan 10 dimensi kapabilitas manufaktur seperti disajikan pada Tabel 1. 
Tabel 1: Sepuluh dimensi kapabilitas manufaktur

\begin{tabular}{|l|l|}
\hline Fleksibilitas produk & $\begin{array}{l}\text { Kemampuan untuk menangani kesulitan, permintaan tidak standar dan } \\
\text { memproduksi produk dengan beragam bentuk, pilihan, ukuran dan warna }\end{array}$ \\
\hline Fleksibilitas volume & Kemampuan untuk menyesuaikan kapasitas produksi secara cepat \\
\hline Fleksibilitas proses & $\begin{array}{l}\text { Kemampuan untuk meproduksi produk dengan biaya yang rendah, } \\
\text { juga perubahan produk yang bervariasi dapat dilakukan dengan mudah. }\end{array}$ \\
\hline Biaya produksi rendah & $\begin{array}{l}\text { Kemampuan untuk meminimasi biaya produksi total (seperti biaya } \\
\text { TKL, material dan biaya operasi). }\end{array}$ \\
\hline $\begin{array}{l}\text { Tingkat Inovasi/Pengenalan } \\
\text { produk baru }\end{array}$ & $\begin{array}{l}\text { Kemampuan untuk mengenalkan peningkatan variasi produk secara } \\
\text { tepat. }\end{array}$ \\
\hline Kecepatan pengiriman & $\begin{array}{l}\text { Kemampuan untuk memastikan jumlah pesanan dan mengantisipasi } \\
\text { waktu kedatangan pesanan. }\end{array}$ \\
\hline Ketergantungan pengiriman & $\begin{array}{l}\text { Kemampuan untuk memastikan jumlah pesanan dan mengantisipasi } \\
\text { waktu kedatangan pesanan. }\end{array}$ \\
\hline Kualitas produk & Kemampuan untuk memproduksi produk dengan performansi standar. \\
\hline Reliabilitas produk & Kemampuan untuk memaksimalkan waktu kerusakan produk \\
\hline Kualitas desain & $\begin{array}{l}\text { Kemampuan untuk menyediakan produk dengan bentuk, model dan } \\
\text { karakteristik yang merupakan keunggulan bersaing. }\end{array}$ \\
\hline
\end{tabular}

Sumber: Vickery, dkk (1993)

\section{STRATEGI BISNIS}

Porter mengklasifikasikan strategi bisnis perusahaan dalam tiga kelompok besar, yaitu overall cost leadership strategy, focus strategy dan pure differentiation strategy, yang masing-masing membutuhkan komitmen dan pengelolaan organisasi secara efektif.

\section{Strategi Kepemimpinan Biaya (Overall Cost Leadership)}

Strategi yang pertama ini muncul pada dekade 1970-an karena populernya konsep experience curve. Strategi ini berusaha untuk mencapai kepemimpinan biaya rendah melalui konstruksi efisiensi atas fasilitas yang ada, pengurangan biaya secara teliti berdasarkan pengalaman, pengendalian biaya dan overhead secara ketat, dan minimisasi biaya pada bidang-bidang seperti penelitian dan pengembangan, pelayanan, tenaga penjualan, periklanan dan sebagainya. Perhatian manajerial pada pengendalian biaya merupakan suatu hal yang mendasar dalam pencapaian tujuan strategi ini.

\section{Strategi Diferensiasi Murni (Pure Differentiation)}

Strategi diferensiasi lebih fokus pada upaya penciptaan sesuatu yang baru dan unik pada produk yang ditawarkan pada konsumen, biasanya perusahaan yang menggunakan strategi tersebut fokus pada segmen tertentu. Pendekatan diferensiasi tersebut dapat dilakukan dengan berbagai bentuk, seperti desain atau brand image, teknologi dan fitur. 


\section{Strategi fokus (focus)}

Strategi yang ketiga mempunyai fokus pada segmen atau pembeli tertentu dengan lini produk tertentu dan pasar geografis tertentu pula. Berkaitan dengan hal tersebut, maka strategi fokus memiliki beberapa bentuk, yaitu fokus dasar pada pencapaian biaya rendah dan diferensiasi serta fokus dasar pada diferensiasi dengan diikuti pencapaian biaya murah.

Miles dan Snow (1978) membedakan pilihan strategi ke dalam empat tipologi, yaitu: (1) prospector, (2) defender, (3) analyzer dan (4) reactor. Prosepector adalah jenis perusahaan yang menggunakan strategi yang mementingkan pada inovasi, dan kreatitas untuk menciptakan produk baru. Perusahaan selalu berusaha untuk menjadi pioneer dalam bersaing, serta rela mengkompensasikan internal efisiensi dalam berinovasi dan berkreasi. Sementara kelompok defender selalu berusaha menciptakan strategi stabilitas dan kelangsungan hidup perusahaan. Fokus perusahaan adalah pada upaya pencapaian stabilitas jangka panjang dan mempertahankan inti bisnisnya (core business), tanpa banyak melakukan perubahan strategi.

Analyzer adalah kelompok perusahaan yang menggunakan kombinasi prospector dengan defender. Artinya perusahaan tidak berani ambil resiko dalam berinovasi, tetapi tetap berupaya menciptakan keunggulan dalam pelayanannya kepada pasar. Kelompok ke empat adalah reactor yang selalu fokus pada efisiensi tanpa mempertimbangkan perubahan lingkungan yang terjadi. Reactor adalah tipe organisasi yang tidak memiliki konsistensi strategi dalam beradaptasi (unstable).

Menurut Smith, dkk (1989), tipologi strategi dari Miles dan Snow (1978) tersebut dapat mencerminkan kompleksitas lingkungan yang dihadapi organisasi dan proses organisasional dari berbagai dimensi, misalnya persaingan, perilaku konsumen, situasi dan respon pasar, teknologi, struktur organisasi dan karakteristik manajerial lainnya. Sementara orientasi teori strategi pada tipologi Porter (1980) hanya menggambarkan perilaku persaingan pasar secara umum.

\section{METODE PENELITIAN}

\section{Desain Sampel}

Populasi dalam penelitian ini adalah produsen/pengelola usaha pengecoran dan rekayasa logam di Ceper dan Tegal. Sampel di Ceper terdiri dari beberapa perusahaan di Solo dan beberapa perusahaan yang berada di dusun Jeblogan, Krenekan, Bakalan Baru, Kurung Baru yang berada di kecamatan Batur (Ceper). Sementara sampel di Tegal terdiri dari beberapa perusahaan yang berada di lingkungan LIK Takaru yang berada desa Damyak, Kecamatan Kramat (jalur Pantura), selain beberapa perusahaan di Lebaksiu (kabupaten Slawi) serta beberapa perusahaan yang berada di kecamatan Talang (dusun Kebasen dan Talang) dan Adiwerna (dusun Lemah dhuwur, Tembok Luwung dan dusun Kalimati).

Pengambilan sampel dalam penelitian ini bersifat nonprobability sampling, artinya tidak seratus persen acak dan ada pertimbangan-pertimbangan untuk tujuan 
tertentu. Sehingga teknik pengambilan sampling dapat dikategorikan sebagai purposive sampling. Pertimbangan lebih pada aspek relevansi di lapangan bahwa perusahaan yang dipilih sebagai sampel hanya perusahaan yang direkomendasikan oleh pihak Koperasi Batur Jaya (Klaten) serta Subdin Perindustrian Takaru (Tegal).

Pengumpulan data dilakukan pada tanggal 18 maret sampai dengan 5 juni 2006, dengan menggunakan kuesioner. Kuesioner didesain dengan model pertanyaan terbuka untuk data pribadi dan alasan responden, dan pertanyaan tertutup mengenai persepsi (kecenderungan penilaian) responden atas dimensi manufacturing task serta strategi bisnis perusahaan. Dari 99 responden yang dijadikan sampel, 43 responden merupakan perusahaan di Ceper dan 56 sisanya adalah perusahaan di Tegal.

\section{Variabel dan Instrumen Penelitian}

Variabel yang diteliti meliputi strategi pemanufakturan (yang diukur dengan menggunakan dimensi ongkos produksi rendah, kualitas dan reliabilitas produk, pengiriman, fleksibilitas dan tingkat inovasi), strategi bisnis serta kinerja operasional pabrik. Masing-masing variabel dirinci ke dalam beberapa pertanyaan dengan pilihan alternatif jawabab berupa sangat setuju (skor 5) samapai sangat tidak setuju (skor 1) dengan mengikuti skala Likert.

Tabel 2: Hasil Pengujian Validitas dan Reliabilitas

\begin{tabular}{|c|l|l|l|l|}
\hline \multirow{2}{*}{ No } & \multicolumn{1}{|c|}{ Variabel } & \multicolumn{2}{c|}{ Validitas } & \multicolumn{1}{c|}{ Reliabilitas } \\
\cline { 3 - 5 } & & Keiser's MSA & Factor loading & Cronbach alpha \\
\hline \multirow{4}{*}{1} & Manufacturing task & & & 0.885 \\
& Dimensi ongkos produksi rendah & 0.633 & $0.726-0.764$ & 0.571 \\
& Dimensi Kualitas & 0.729 & $0.643-0.768$ & 0.707 \\
& Dimensi Fleksibilitas & 0.738 & $0.698-0.825$ & 0.707 \\
& Dimensi Pengiriman Produk & 0.754 & $0.530-0.806$ & 0.743 \\
& Dimensi Inovasi & 0.655 & $0.785-0.882$ & 0.762 \\
\hline 2 & Startegi Bisnis & 0.694 & $0.587-0.853$ & 0.756 \\
\hline 3 & Kinerja & 0.500 & $0.884-0.911$ & 0.568 \\
\hline
\end{tabular}

Pengujian validitas dan reliabilitas instrumen penelitian dengan menggunakan confirmatory factor analysis melalui principle component analysis dengan metode varimax otation. Untuk mengetahui bahwa pertanyaan-pertanyaan yang digunakan adalah valid dapat dilihat nilai-nilai hasil pengujian: Kaiser-Meyer-Olkin Measure of Sampling (Keiser's MSA) dengan kriteria >0,5 dan nilai factor loading dengan kriteria >0,4 (Riyanto, 1997). Sementara untuk melihat reliabilitas masing-masing variabel peneliti menggunakan koefisien Cronbach alpha, suatu variabel dikatakan reliabel jika hasil pengujian reliabilitas menunjukkan nilai cronbach alpha $>0,5$. Hasil yang didapat dari pengujian validitas dan reliabilitas secara lengkap disajikan pada Tabel 2. 
ANALISIS DATA

Untuk menjawab masalah yang berkaitan dengan misfit-score dan besarnya pengaruh kesesuaian variabel strategi pemanufakturan dan strategi bisnis pada kinerja opwerasional, digunakan teknik analisis regresi linier sederhana. Dalam model regresi sederhana ini tidak menggunakan data yang sifatnya runtut waktu (time series), dan dalam penelitian-penelitian perilaku tidak digunakan untuk memprediksi suatu fenomena, tetapi hanya digunakan untuk menjelaskan fenomena, sehingga tidak dilakukan uji asumsi klasik. Seharusnya yang perlu dicermati adalah multikoloniaritas, yaitu adanya hubungan sempurna di antara variabel independen pada model persamaan regresinya. Akan tetapi karena dalam penelitian ini menggunakan skor euclidian distance atau deviasi dari dua variabel bebas, maka multikoloniaritas dalam model ini tidak perlu dideteksi. Persamaan yang digunakan adalah $Y=\beta_{0}+\beta_{1}$ Dist. $\times 1 . \times 2+\varepsilon$,

Untuk $Y=$ kinerja operasional sebagai variabel dependen; $\beta_{0}$ adalah konstanta; $\beta_{1}$ adalah slope atau koefisien regresi.

Dist. x1.x2 adalah Euclidian distance strategi pemanufakturan-strategi bisnis; Dist adalah Euclidian distance atau miskesesuaian hubungan score antara variabel strategi pemanufakturan, strategi bisnis dan pilihan proses. Prosedur penghitungan nilai Euclidian distance dengan cara menjumlahkan besarnya deviasi atau selisih skor ideal untuk masing masing kelompok ideal dengan rumus Dist $=\Sigma \sqrt{ }\left(\mathbf{X}_{\text {-id }}-\mathbf{X}\right.$. ac) $)^{2}$

$\mathrm{X}_{\text {-id }}$ besarnya skor ideal variabel kontijensi

$X_{\text {-ac }}$ besarnya skor aktual variabel kontijensi

\section{PENGUJIAN AWAL}

\section{Uji Bias Respon}

Sebelum mendeteksi misfit-score dari variabel strategi pemanufakturan dengan strategi bisnis dan menguji pengaruhnya pada kinerja, dalam penelitian ini perlu dilakukan uji bias respon dan uji beda (strategi pemanufakturan). Uji bias respon variabel kendali dan variabel penelitian dilakukan dengan maksud untuk mendeteksi adanya perbedaan yang signifikan antara responden yang mengisi kuesioner secara langsung dan tidak langsung. Jika hasil pengujian bias respon dengan uji beda ternyata tidak signifikan, maka artinya jawaban responden dari dua kelompok tidak menunjukkan perbedaan sehingga dapat dilakukan analisis lebih lanjut. 
Tabel 3: Uji Bias Respon Variabel Penelitian

\begin{tabular}{|l|c|c|c|c|}
\hline \multicolumn{1}{|c|}{ Variabel } & $\begin{array}{c}\text { Kode } \\
\text { Kelompok }\end{array}$ & N & F & Sig. \\
\hline Manufacturing Task & 1 & 62 & 0.018 & 0.928 \\
& 2 & 37 & & \\
\hline Strategi bisnis & 1 & 99 & & \\
& 2 & 62 & 0.108 & 0.743 \\
& Total & 37 & & \\
\hline Kinerja & 1 & 69 & & 0.369 \\
& 2 & 37 & 0.816 & \\
\hline
\end{tabular}

Keterangan:

(1) Jawaban secara langsung

(2) Jawaban secara tidak langsung

Sumber: Data primer diolah, 2006

Hasil pengujian pada Tabel 3 menunjukkan bahwa ternyata perbedaan rerata melalui uji $\mathrm{F}$ pada karakteristik responden untuk masing-masing kelompok tidak signifikan dengan nilai $p$ ( $p$ value) di atas 0,05 , yaitu untuk tingkat pendidikan 0,430 , pengalaman bisnis 0,115 , manufacturing task 0,926 , strategi bisnis 0,743 ; dan kinerja 0,369. Jadi dapat disimpulkan bahwa tidak ada perbedaan yang signifikan atas variabel kendali ataupun variabel penelitian pada kelompok responden yang menjawab langsung dan tidak langsung.

\section{Uji beda strategi pemanufakturan}

Untuk menunjukkan bahwa kelompok differentiators dan kelompok efficient innovators mempunyai keputusan kompetensi pemanufakturan yang berbeda, artinya memiliki strategi pemanufakturan yang perbedaannya signifikan, maka kedua kelompok tersebut perlu diuji beda dengan menggunakan analisis perbedaan rerata model anova (analysis compare means one way anova) pada kedua kelompok tersebut.

Tabel 4: Uji Beda Kelompok Strategi Pemanufakturan

\begin{tabular}{|l|c|c|c|c|}
\hline Kode Kelompok & $\mathbf{N}$ & Mean & Std Deviasi & F \\
\hline - $\quad$ Efficient-Innovators (1) & 76 & 81.2362 & 13.8452 & \multirow{2}{*}{$22.492^{\star \star}$} \\
\hline - Differentiators (2) & 23 & 86.0909 & 13.7105 & \multirow{2}{*}{ - } \\
\hline
\end{tabular}

Signifikan pada $p<0.05(*)$

Tabel 4 menunjukkan bahwa untuk elemen manufacturing task mempunyai nilai $F$ signifikan pada nilai $p<0.05$ artinya baik kelompok differentiators Vs efficientinnovators mempunyai perbedaan pilihan kompetensi manufaktur. Untuk kelompok efficient -innovators (kode 1) dan differentiators (kode2). 


\section{HASIL DAN PEMBAHASAN}

\section{Perbedaan Pilihan Kompetensi di Ceper dan Tegal}

Sesuai dengan hasil konfirmasi analisis faktor yang sudah dilakukan, maka penjelasan strategi pemanufakturan akan dijabarkan pendiskripsian 5 dimensi manufacturing task sebagai elemen pertama strategi manfaktur dengan cara menghitung nilai rerata masing-masing dimensi untuk masing-masing sampel (komparasi antara Ceper dengan Tegal). Tabel 5 menunjukkan nilai rerata, nilai maksimum dan minimun serta nilai mean total dari masing-masing dimensi.

Tabel 5: Diskripsi Statistik Dimensi Manufactruing Task

\begin{tabular}{|c|c|c|c|c|c|}
\hline Dimensi Manufacturing Task & $\mathrm{N}$ & Min & $\max$ & Mean & total \\
\hline \multicolumn{6}{|l|}{ Ongkos Produksi Rendah } \\
\hline Ceper & 43 & 3.00 & 12.99 & 10.64 & \multirow[b]{2}{*}{9.04} \\
\hline Tegal & 56 & 4.21 & 8.33 & 7.44 & \\
\hline \multicolumn{6}{|l|}{ Kualitas } \\
\hline Ceper & 43 & 4.14 & 32.12 & 22.58 & \multirow[b]{2}{*}{23.67} \\
\hline Tegal & 56 & 6.24 & 34.15 & 24.76 & \\
\hline \multicolumn{6}{|l|}{ Fleksibilitas } \\
\hline Ceper & 43 & 7.82 & 30.12 & 28.76 & \multirow[b]{2}{*}{29.75} \\
\hline Tegal & 56 & 6.14 & 33.33 & 30.74 & \\
\hline \multicolumn{6}{|l|}{ Pengiriman Produk } \\
\hline Ceper & 43 & 7.33 & 16.21 & 15.11 & \multirow[b]{2}{*}{14.53} \\
\hline Tegal & 56 & 7.33 & 14.99 & 13.95 & \\
\hline \multicolumn{6}{|l|}{ Tingkat Inovasi } \\
\hline Ceper & 43 & 2.33 & 10.33 & 9.30 & \multirow[b]{2}{*}{9.58} \\
\hline Tegal & 56 & 2.66 & 12.99 & 9.86 & \\
\hline
\end{tabular}

Sumber: Data Primer Diolah, 2006

\section{Dimensi ongkos produksi rendah}

Perbedaan nilai rerata akan dimensi ongkos produksi rendah untuk Ceper dan Tegal relatif kecil. Hal ini didukung dengan hasil pengamatan di lapangan bahwa perusahaan di Ceper ataupun Tegal dalam proses produksi tidak memberdayakan karyawan yang khusus menangani operasional pabrik. Kebanyakan pemilik sendiri yang melakukan proses inspeksi di parik. Tingginya nilai rerata di Ceper kemungkinan disebabkan kebanyakan perusahaan di Ceper yang sampai saat ini bisa survive adalah kelompok perusahaan yang benar-benar sudah melakukan efisiensi sendiri untuk melakukan proses pengecoran, hal ini didukung dengan mesin dan peralatan yang ada merupakan produk impor. Sementara dari hasil wawancara dengan beberapa pengusaha di Tegal penggunaan mesin untuk proses produksi masih semi manual, dan kebanyakan perusahaan yang memproduksi hydrant dan komponen permesinan lainnya tidak melakukan pengecoran sendiri, melainkan mereka membeli bahan setengah jadi dari para produsen di Ceper. 


\section{Dimensi kualitas}

Tabel 5 menunjukkan bahwa nilai rerata dimensi kualitas di Tegal lebih tinggi, hal ini kemungkinan disebabkan karena perilaku para pengusaha di Tegal selalu positif dalam upaya pelatihan dan pengembangan pengusaan teknologi yang selalu diselenggarakan oleh pihak subdin perindustrian. Berbeda halnya dengan para pengusaha di Ceper yang motivasi untuk program-program semacam itu rendah. Sikap agresif pihak subdin perindustrian Tegal memotivasi para pengusaha untuk meningkatkan kemampuan teknologi, bahkan pihak subdin perindustrian juga berperan sebagai pihak pemasaran/perantara. Hasil wawancara dengan Bapak Abu Bakar sebagai seksi pengembangan ketrampilan pengrajin UKM menyebutkan dalam kurun waktu satu tahun (tahun 2005) pihak subdin perindustrian khususnya Koperasi Lik Takaru telah menyelenggarakan 13 acara pelatihan, animo pengusaha di Tegal untuk mengikuti program-program tersebut sangat tinggi. Pembinaan di Lapangan untuk mencapai tingkat presisi kualitas produk yang tinggi, kebanyakan rekanan (mitra perusahaan) memperkerjakan teknisi mereka untuk terlibat langsung dalam pabrik. Dengan begitu proses transfer pengetahuan/teknologi di Tegal lebih besar peluangnya.

\section{Dimensi fleksibilitas}

Kebanyakan pengusaha di Ceper ataupun Tegal selalu mempunyai kesiapan, jika ada perubahan desain produk, jumlah dan spesifikasi kualitas yang diminta pelanggan. Pada dasarnya mereka berproduksi sesuai dengan permintaan pelanggan, bedanya perusahaan yang sudah dapat melakukan standardisasi secara massal sudah mempersiapkan diri untuk menjamin kontinyuitas proses produksi, yaitu dengan menggunakan jenset atau kerjasama dengan PLN untuk pemberitahuan sebelum listrik mati.

Nilai rerata fleksibilitas di Tegal lebih tinggi, hal ini didukung dari hasil pengamatan bahwa kebanyakan hubungan antar pengusaha di Ceper relatif tertutup (banyak bangunan pabrik dipagar tinggi/tertutup). Berbeda dengan Tegal, kebanyakan perusahaan masih mempunyai kepercayaan dengan perusahaan pesaing, bahkan tidak sering order mereka subkontrakan pada pengusaha lain. Kekhawatiran akan pelaku pesaing untuk merebut pasar dan meniru produk dirasakan oleh pengusaha di Ceper dan Tegal, bahkan pemasaran melalui internet oleh CV AMEX tidak dilakukan lagi, karena mendorong munculnya produk imitator. Dengan tidak adanya kesepakatan antar pengusaha tersebut menyebabkan kompetisi menjadi tidak sehat, karena persaingan tidak berdasarkan pada kualitas tetapi harga. Selanjutnya hal ini akan menekan tingkat margin yang diperoleh.

\section{Dimensi pengiriman produk}

Dimensi pengiriman produk antara perusahaan di Ceper dan Tegal selisih reratanya relatif kecil. Hasil wawancara dengan beberapa perusahaan besar di Tegal yang sudah melakukan kemitraan baik dengan perusahaan/wholeseller lokal (seperti 
Komatsu, PT Kobuta, PT Nataraya dan subkontraktor ASTRA lainnya) ataupun Luar Negeri (seperti perusahaan Jepang "SANWA"), mereka umumnya tidak mengatur proses pengiriman barang. Kebanyakan pelanggan mengatur proses pengiriman barang pesanan mereka dengan menunjuk perusahaan tertentu sebagai tempat penampungan sementara, bahkan pola pengambilan pesanan sudah dilakukan terjadwal. Untuk pengrajin plat dan mesin kapal di Tegal juga kebanyakan mereka tidak melakukan pemasaran sendiri, melainkan sudah ada kemitraan dengan para pengecer komponen alat-alat berat yang juga mengatur masalah proses pengiriman pesanan.

Sementara hasil wawancara dengan beberapa perusahaan di Klaten seperti CV AMEX, PT Baja Kurnia dan PT Rekatama Karya Mandiri menunjukkan bahwa pihak perusahaan bertanggung jawab penuh atas proses pengiriman produk. Beberapa perusahaan di Klaten juga telah melakukan kemitraan dengan perusahaan lokal ataupun luar negeri, seperti PT Yamindo, PT Barata Industry (Surabaya, komponen alat berat), PT KHS (Karya Hidup Sentosa) Yogyakarta untuk memasok komponen alat-alat pertanian, PAL (galangan kapal), Mega Rubber Factory, PT Samitex serta banyak lagi.

\section{Dimensi tingkat inovasi}

Perbedaan nilai rerata inovasi pada Tabel 5 antara Ceper dan Tegal relatif kecil dan rendah. Hal ini relevan dengan hasil wawancara di lapangan bahwa kebanyakan perubahan desain produk sesuai dengan permintaan pelanggan, kecuali pada komponen pengerjaan plat dan rekayasa yang seringnya mempunyai desain baru sesuai dengan perkembangan pasar untuk ditawarkan pada pelanggan. Berbeda dengan kelompok permesinan yang kebanyakan mereka memproduksi produk yang perubahan variasi/desain relatif kecil. Dan perubahan variasi/desain produk ini dilakukan jika memang ada perubahan akan fungsi dari komponen permesinan yang dipesan pelanggan. Untuk pembuatan matras baru biayanya dibebankan pada pelanggan, jika jumlah pemesanan komponen mesin sedikit. Hal ini disebabkan kemampuan inovasi matras baru masih dilakukan dengan cara trial and error.

\section{Penentuan Nilai Miskesesuaian hubungan Score dengan Euclidean Distance}

Kesesuaian hubungan atau profil ideal (ideal profile) yang dimaksud adalah kesesuaian keputusan pilihan kompetensi di bidang manufaktur dengan strategi bisnis sebagai kesesuaian hubungan vertikal Ideal profile masing-masing pilihan kompetensi manufaktur sebagai elemen strategi pemanufakturan. Pada kelompok efficient-innovators dan differentiators yang kesesuaian hubungan dengan strategi bisnis defenders dan prospectors didasarkan pada pendekatan teoritis. Skor profil ideal untuk kelompok diferentiators akan mempunyai skor total sebesar 35 (kelompok prospectors) dan skor total kelompok efficient - innovators adalah 7 (defenders). 
Dalam menentukan derajat kesesuaian hubungan digunakan cara menghitung dan menjumlahkan besarnya deviasi atau miskesesuaian hubungan score atau disebut euclidian distance (Dist), yaitu selisih skor ideal masing-masing variabel kontijensi (strategi bisnis dan aspek pasar atau karakteristik permintaan)

Hasil pengolahan statistik diskriptif variabel strategi pemanufakturan menunjukkan bahwa nilai rerata atau mean, standar deviasi dan range.berturut-turut $85,0409,13,71$ dan 44,37. Dalam proses pengolahan data untuk analisis regresi, peneliti menggunakan mean split dari elemen strategi manufaktur. Untuk elemen manufacturing task (pilihan kompetensi di bidang manufaktur) skor untuk masingmasing kelompok dibedakan berdasarkan nilai rerata. Jika di atas 85.0409, maka nilai jawaban responden tersebut akan dikelompokkan sebagai kelompok differentiators. Selanjutnya konfigurasi ideal kelompok tersebut didukung dengan keputusan strategi bisnis kategori prospectors. Sebaliknya kelompok efficient - innovators merupakan kelompok responden yang nilainya di bawah 85.0409, yang akan lebih kesesuaian hubungandengan strategi defender.

\section{Analisis Regresi}

\section{Analisis kelompok efficient - innovators}

Kelompok efficient-innovators adalah kelompok perusahaan yang mempunyai karakteristik bertahan untuk selalu mencapai efisiensi (ongkos produksi rendah) dan kurang agresif dalam melakukan pemasaran ataupun menciptakan pasar baru. Pendekatan taksonomi yang dikembangkan oleh Sum, Kou dan Chen (2004) mendiskripsikan karakteristik kelompok SME di Singapura yang masuk kelompok efficient - innovators adalah kelompok perusahaan yang fokus utamanya adalah pencapaian efisiensi. Dan untuk selalu dapat kompetitif perusahaan dituntut untuk selalu berinovasi, tetapi kemampuan inovasi tidak menonjolkan keunikan produk melainkan selalu mengikuti perkembangan pasar, sehingga biaya inovasi dapat efisien. Kompetensi untuk pengiriman produk khususnya kecepatan pengiriman produk juga diprioritaskan.

Dari sejumlah 76 perusahaan yang tergolong kelompok efficient - innovators seharusnya melakukan upaya-upaya untuk pencapaian efisiensi produksi. Tetapi dari wawancara yang dilakukan masih banyak perusahaan yang tidak melaksanakan tindakan inspeksi di pabrik secara kontinyu, padahal banyak perusahaan yang menyadari bahwa kegiatan proses produksi belum dapat optimal. Kurang efisiennya proses produksi disebabkan karena pemenuhan order dilakukan dengan trial error dalam pembuatan matras, kurangnya teknisi atau karyawan yang ahli dan pengusaan karyawan akan mesin dan peralatan impor juga masih kurang. Banyak perusahaan yang menanggung biaya maintenance (perawatan) mesin yang cukup besar karena komponen mesin harus diimpor dari LN. Cara mengatasi kendala selama proses produksi (semacam listrik mati) juga belum dapat di atasi oleh beberapa perusahaan, sehingga pencapaian efisiensi produksi sulit. 
Tabel 6: Hasil Regresi Manufacturing Task

\begin{tabular}{|l|c|c|}
\hline \multicolumn{1}{|c|}{ Keterangan } & $\begin{array}{c}\text { Efficient-Innovators } \\
(\mathbf{N}=76)\end{array}$ & $\begin{array}{c}\text { Differentiators } \\
(\mathbf{N}=\mathbf{2 3})\end{array}$ \\
\hline Koefisien (b) & 0.235 & $-0,390^{\star *}$ \\
\hline $\mathrm{t}$ & 2.075 & $-2,416$ \\
\hline Konstanta & 5.481 & 7.536 \\
\hline R Square & 0.235 & 0.090 \\
\hline
\end{tabular}

** Signifikan $p<0,05$

Tabel 6 menunjukkan hasil perhitungan dengan menggunakan uji t. Nilai statistik $\mathrm{t}$ hitung hasil regresi adalah 2,075, sementara nilai statistik t Tabel (tingkat siginifikansi/alpha 5\%; $\mathrm{df}=\mathrm{N}-2=76-2=74$ ) adalah 2,6802. Hasil t hitung ternyata lebih kecil dari $t$ Tabel. Di samping itu dijetahui pula nilai koefisien regresi (standardized) hasilnya positif $(0,235)$ dan tidak signifikan atau $p>0,05$. Artinya antara elemen manufacturing task dengan strategi bisnis pada kelompok efficientinnovators tidak ada kesesuaian. Sehingga dapat disimpulkan bahwa pada kelompok efficient-innovators tidak terdapat kesesuaian dengan pilihan strategi bisnis yang dipilih, sehingga tidak mempengaruhi kinerja

Hasil analisis regresi ini didukung dengan kondisi di lapangan, bahwa pada saat ini mayoritas perusahaan cor logam (khususnya kelompok pengecoran Fero) menghadapi masalah utama pada bahan baku kokas. Tingginya harga kokas dan langkanya kokas mempersulit perusahaan dalam upaya pencapaian ongkos produksi rendah, karena kenyataannya bahan baku kokas tersebut diimpor dari Cina. Sementara kondisi nilai rupiah yang terpuruk dan diberlakukannya peraturan pemerintah Cina untuk membatasi ekspor kokas (batu bara) menyebabkan kelangkaan bahan baku. Jenis kokas yang digunakan adalah kokas metalurgi (metallurgical coke), yaitu kokas yang dibuat dari jenis batu bara antrasit (yang kualitas tersebut jarang ditemukan pada pertambangan batubara lokal), yang mempunyai sifat dan kesarangan porositas tertentu, sehingga dapat digunakan untuk peleburan bijih besi.

Kelompok pengerjaan plat ataupun rekayasa dan konstruksi yang masuk dalam kelompok efficient - innovators juga menghadapi masalah kelangkaan bahan baku scrapt (rongsokan logam) dan kuningan. Sedikitnya pengepul (pengumpul) barang-barang rongsokan menyebakan bahan baku tersebut langka, kebanyakan pengepul berada di luar kota seperti Juwono Semarang dan Cirebon, sehingga menyebabkan penambahan biaya transportasi untuk pengadaan bahan baku. Temuan-temuan di lapangan tersebut memperjelas timbulnya ketidaksesuaian keputusan pilihan kompetensi manufatur pada perusahaan yang fokus pada efisiensi (defenders). 


\section{Analisis kelompok differentiators}

Kelompok Differentitors merupakan kelompok perusahaan yang selalu agresif memasarkan produk dan memperluas pasar, dan mempunyai motivasi kuat untuk melakukan investasi perluasan produksi untuk jangka panjang dan selalu menciptakan produk inovasi produk. Kelompok tersebut juga memprioritaskan kualitas dan reliabilitas produk, sehingga untuk penciptaan keunikan produk atau produk baru biarpun membutuhkan biaya produksi yang besar tidak menjadi permasalahan. Tabel 6 menunjukkan nilai koefisien regresi (standardized) negatif yaitu sebesar - 0,390 dan tidak signifikan atau pada $p>0,082$, artinya tidak ada kesesuaian keputusan pilihan kompetensi dengan strategi pada kelompok tersebut. Hasil ini didukung dengan misfit- score yang relatif kecil.

Berdasarkan hasil wawancara dan pengamatan, rendahnya kesesuaian keputusan pilihan kompetensi dengan strategi bisnis adalah karena pada kenyataannya perusahaan dalam kelompok tersebut kurang agresif dalam melakukan pemasaran dan perluasan pangsa pasar. Misalnya untuk perusahaan-perusahaan di Tegal yang kegiatan pemasarannya masih dimediasi oleh PT Nataraya dan subdin perindustrian kabupaten Tegal. Untuk pesanan dari beberapa subkontraktor ASTRA ataupun perusahaan lokal dan LN, biasanya semua perusahaan diberi kesempatan untuk mencoba menerima pesanan yang membutuhkan tingkat presisi yang tinggi. Kebanyakan perusahaan menyerah/tidak sanggup menerima pesanan. karena membutuhkan biaya desai pembuatan prototype yang besar. Kompetisi alami akan menyeleksi perusahaan yang tangguh dan mampu memenuhi standar spesifikasi kualitas yang tinggi, tetapi prakteknya dalam pengerjaan pesanan perusahaan masih dibantu teknisi/ahli dari pihak PT Komatsu atau PT Nataraya sebagai mediator pemasaran/pembina teknologi. Begitu pula dengan perusahaan-perusahaan di Ceper yang kebanyakan juga kurang agresif melakukan pemasaran, untuk kegiatan pemasaran masih menggunakan mediator koperasi Batur Jaya.

Pada kondisi sekarang ini aktivitas dan kegiatan yang dilakukan oleh pihak koperasi relatif sedikit. Hal ini disebabkan karena animo atau respon pengusaha untuk menghadiri program/kegiatan yang diselenggarakan pihak koperasi sangat rendah. Perilaku pengusaha di Ceper sangat bertolak belakang dengan perilaku pengusaha di Tegal, yang mempunyai motivasi cukup tinggi dalam meningkatkan ketrampilan dan kemampuan teknologi mereka.

Sedikitnya jumlah perusahaan dalam kelompok tersebut sangat sesuai dengan realitas di lapangan, bahwa masih sedikit perusahaan yang berhasil menjalin kemitraan. Hal ini mengindikasi masih sedikit perusahaan yang mampu menghasilkan produk dengan kualitas dan reliabilitas produk tinggi. Rendahnya tingkat kesesuaian tersebut juga diprediksi disebabkan keengganan perusahaan untuk berinvestasi jangka panjang serta sedikitnya dana yang tersedia untuk perbaikan kualitas, meskipun pihak perbankan sangat memberi kemudahan bagi perusahaan. Alasannya adalah lambatnya perputaran penghasilan menyebabkan tidak seimbangnya marjin yang diterima dengan beban bunga yang harus dibayar 
perusahaan pada bank. Kebanyakan mitra perusahaan melakukan pembayaran setelah pesanan dikirim, proses produksi sampai pengiriman membutuhkan waktu 3 sampai 4 bulan. Sementara itu beban bunga yang harus ditanggung selama empat bulan tersebut tidak tertutupi oleh marjin yang diperoleh.

\section{IMPLIKASI}

Satu hal yang menarik untuk diteliti lebih lanjut berkaitan dengan teori konfigurasi ideal menambahkan elemen lain sebagai elemen strategi pemanufakturan, misalnya elemen keputusan struktural dan infrastruktural pabrik yang sesuai dengan aspek pasar ataupun pilihan proses yang digunakan. Di samping itu perlu dilakukan pengujian konfigurasional teori pada sampel yang heterogen dan perusahaan selain industri pengecoran logam. Kenyataan di lapangan, bangkrutnya perusahaan di sentra industri logam dikarenakan faktor bahan baku (kokas, iron dan scrapt) sebagai penyebab kinerja perusahaan saat ini jelek. Hal ini diprediksi peneliti sebagai salah satu penyebab rendahnya nilai misfit-score, dan sulit untuk memprediksi lebih lanjut besarnya pengaruh kesesuaian elemen pilihan kompetensi manufaktur dengan strategi bisnis pada kinerja. Karena realitasanya, kelangkaan bahan baku menyebabkan pengusaha kesulitan untuk mengembangkan pilihan kompetensi di bidang manufaktur untuk mendukung strategi bisnis mereka. Untuk itu penelitian yang akan datang menambah sampel (perusahaan pada sentra logam di Bandung ataupun Pasuruan).

Makna lain yang dapat diambil dari hasil penelitian ini adalah saran untuk praktisi dan dapat dijadikan masukan informasi untuk pihak Pemda selaku pembuat kebijakan dan peraturan daerah agar dapat menciptakan iklim kondusif untuk pertumbuhan industri logam.

\section{REFERENSI}

Anand Gopesh \& Ward, P.T. (2004). "Kesesuaian hubungan, Flexibility and Performance in Manufacturing: Coping With Dynamic Environments", Journal of Production and Operation Management, Vol.13 (4):p. 369-385

Avella, L., Fernandez, E., and Vazquez. (1992). "Taxonomy of The Manufacturing Strategies of Large Spanish Industrial Companies", International Journal of Production and Management, Vol.36(11):p. 3113-3134

Day, G.S., Wensley, R. (1988). "Assesing Advantage: A Framework For Diagnosing Competitive Superiority", Journal of Marketing, Vol.52: p.1-20

Drazin, R., Van De Ven, A.H. (1985). "Alternatif Form of Kesesuaian hubunganin Contigency Theory", Administrative Science Quarterly, Vol.30:p. 514-539 
Ferdows, K., De Meyer, A. (1990). "Lasting Improvement in Manufacturing Performance: In Search of a New Theory", Journal of Operation Management, Vol.9(2): p. 168-184.

Galbraith, J.R., Nathanson, D.A. (1978). Strategy Implementation: The Role of Structure and Process, St. Paul, Minn: West.

Hayes, R.H., Wheelwright, S.C. (1984). "Restoring Our Competitive Edge: Competing Through Manufacturing", Wiley: New York.

Heizer, J \& Render. (2004). Operation Management Seventh Edition, Prentice HallUSA.

Miles, R.E., Snow, C.C. (1978). Organizational Strategy, Structure and Process, New York: Mc. Graw Hill Book Company.

Miller, J.G. (1987). "The Structural and Environmental Correlates of Business Strategy", Strategic Management Journal, Vol.8(1): p.55-76.

Miller, J.G., Roth, A.V. (1988). Manufacturing Strategies: Executives Summary of The 1988 North American Manufacturing Future Survey.

Miller, J.G., Roth, A.V. (1994). "A Taxonomy of Manufacturing Strategies", Management Science, Vol. 40 (3):p. 285-304.

Mintzberg, H. (1978). "Pattern in Strategy Formulation", Management Science,Vol.24 (9):p. 934-948.

Peterson, R.A., Kozmetsky \& Ridgway, N.M. (1983). "Perceived Causes of Small Business Failures: A Research Note", American Journal of Small Business, Vol.(1); p.15-19.

Porter, M. (1985). Competitive Advantage: Creating and Sustaining Superior Performance, New York: Free Press.

Porter, M.E. (1980). Competitives Strategies: Techniques for Analyzing Industries and Competitors, New York: Free Pres.

Riyanto, B. (1999). "The Effect of Attitude, Strategy and Decentralization on The Effectiveness of Budget Participation", Journal Riset Akuntansi Indonesia Vol.2 (2): p. 136-153.

Roth, A.V., Miller, J.G. (1992). "Sucsess Factors in Manufacturing", Business horizon, Vol.35(4):p. 73-81.

Sasono, A. (2002). "Implementasi Kebijakan Tentang Lembaga Keuangan Konvensional dan Syariah Terhadap Kinerja UKM", Makalah disampaikan pada Seminar Sehari di Hotel Santika, Semarang 13 Juni. 
Skinner, W. (1969). "Manufacturing - Missing Link in Corporate Strategy", Harvard Business Review, Vol.47(3):p.136-145.

, (1974). "The Focused Factory", Harvard Business Review, Vol.15(4): p. 113-122. (1978). "Manufacturing in The Corporate Strategy", New York: Wiley.

Smith, K.G., Guthrie, J.P., Chen, M.J. (1989). "Strategy, Size and Performance" Organizational Studies, Vol.10 (1): p.63-81.

Stoubough, R., Telesio, P. (1983). "Match Manufacturing Policies and Product Strategy", Harvard Business Review, March-April:p. 113-120.

Sum, Chee-Chuong, Lynn Shih-Ju Kou \& Sheng Chen. (2004). "A Taxonomy of Operations Strategies of High Performing Small and Medium Enterprises in Singapore", International Journal of Operation and Production Management, Vol.24 (3): p. 321-345.

Swamidass, D.M., Newell, W.T. (1987). "Manufacturing Strategy, Environmental Uncertainty and Performance: A Path Analityc Model", Management Science, Vol.33(4): p.509-524.

Vickery, S.K., Droge,C., Markland, R.R. (1993). "Production Competence and Business Strategy: Do They Effect Business Performance: An Empirical Study of Singapore Manufacturers", Journal of Operation Management, Vol.13(2):p. 99-115.

Voss, C.a. (1995). "Alternative Paradigms For Manufacturing Strategy", International Journal of Operation and Production Management, Vol.15(4):p. 5-16.

Ward, P.T., Duray, R. (2000). "Manufacturing Strategy in Context: Environment, Competitive Strategy and Manufacturing Strategy", Journal of Operation Management, Vol.18: p 123-138. 